\title{
Chemical Characterization and Estimation of Cheka: A Traditional Food and Drink
}

\author{
Adane Gebresilassie Hailemariam \\ Department of Chemistry, Dire Dawa University, Dire Dawa, Ethiopia \\ Email address: \\ adanegebre19@yahoo.com \\ To cite this article: \\ Adane Gebresilassie Hailemariam. Chemical Characterization and Estimation of Cheka: A Traditional Food and Drink. American Journal of \\ Applied Chemistry. Vol. 5, No. 5, 2017, pp. 73-83. doi: 10.11648/j.ajac.20170505.12
}

Received: May 2, 2017; Accepted: June 6, 2017; Published: October 17, 2017

\begin{abstract}
Cheka is the most commonly used traditional food and drink for people who live around Konso and Derashe special woredas. The characterization of carbohydrate, protein and alcohol with estimation of protein and carbohydrate in cheka was done. The result obtained for all tests of alcohol, carbohydrate and proteins is positive result confirming their prescience in cheka. Most of cheka users have a body mass index (BMI) in the normal range which shows the positive impact of cheka, on human health.
\end{abstract}

Keywords: Cheka, Derashe, Konso

\section{Introduction}

Cheka is the most commonly used traditional food and drink for peoples who live around Konso and Derashe special woredas. Konso peoples take the upper hand in using cheka, and they have a long history with it. These peoples are the first in the southern part of Ethiopia to use cheka as a food. Derashe peoples are the second, next to Konso peoples to use cheka, but the ingredients and methods of preparation of cheka in different places has a slight difference. Today cheka is found almost in all parts of southern Ethiopia due to its suitability to do hard works, easily availability of its ingredients and low cost.

Proteins make up the large part of the mammal body, they hold it together and they run it. They are found in all living cells. They are the principal material; of skin muscles, tendons, nerves and blood of enzymes, antibodies and many hormones chemically proteins are high polymers. They are polyamides and the monomers form which they are derived is the Alfa amino carboxylic acids. A single protein molecule contains hundreds or even thousands of amino acid units. These units can be of twenty odd different kinds. The number of different combination of these units yields different number of protein molecules. The it is likely that tens of thousands of different proteins are required to make up and run an animal body, and this set of protein is not identical with the set required by an animal of different kind only the nuclide acid, which control heredity can challenge the position of proteins and nucleic acids are important because they direct the synthesis of proteins. [17]

Every function in the living cell depends in proteins motions and locomotion of cells and organism depends on contractile proteins. Example muscles. The catalysis of all biochemical reaction is done by enzymes, which contains protein. The structure of cells, and the extra cellular matrix in which they are imbedded, is largely made of protein. The transport of materials in body fluids depends of proteins. Example, blood. The receptors for hormones and other signaling molecules are proteins. Proteins are an essential nutrients for hetrotrophs. the transcription factors that turn genes on and off to guide the differentiation of the cell and its later responsiveness to signal reaching it are proteins, and many more proteins are truly the physical bases of life many foods contains protein, but the best source are beef , poultry builds up, maintenance and replaces the tissues in our body. Our body uses the protein we eat to make lots of specialized protein molecules that have specific function. For example, our body protein to make hemoglobin which is the part of red blood cell that carries oxygen to every part of our body. [19]

An alcohol is any organic compound in which hydroxyl functional group (-OH) is bonded to a carbon atom, usually connected to other carbon or hydrogen atoms. An important 
class, the simple acyclic alcohols with the general formula for which is $\mathrm{CnH}_{2 \mathrm{n}}+\mathrm{OH}$. In common speech the word alcohol refers specially to ethanol. Alcohols can be thought of as organic derivatives of water in which one of the hydrogen is replaced by an organic group, $\mathrm{H}-\mathrm{O}-\mathrm{H}$ versus $\mathrm{R}-\mathrm{OH}$. Alcohols occur widely in nature and have much industrial and pharmaceutical application. Methanol and ethanol for instance, are two of the most important of all industrial chemicals prior to the development of the modern chemical industry. Methanol was prepared by heating wood in the absence of air and thus come to be called wood alcohol. Today, approximately 1.7 billion of methanol are manufactured each year in the united states by catalytic reduction of carbon monoxide with hydrogen gas. [13]

The common ingredients of cheka are sorghum, maize, malt and water. Additional ingredients are used in different places, according to the availability of raw materials suitable for cheka preparation. Derashe people's cheka contains cabbage and Maringa leaf in addition to the common ingredients; while Konso's cheka is prepared from common ingredients only.

Maize is facultative long night plant and flowers in certain number of growing degree days $>50^{\circ} \mathrm{C}$. in the environment to which it is adapted. The magnitude of the influence that long night have on the number of days that must pass before maize flowers genetically prescribed and regulated by phytochrome system. The kernel of maize has a pericarp of the fruit fused with the seed coat, typically of the grass, and the entire kernel is often referred to as the seed. When ground in to flaurs, maize yields more flaurs with much less bran, than wheat does. How ever it lacks the protein gluten of wheat and therefore makes baked goods with poor rising capability and coherence. Its shortage may cause lack of two key amino acids. [8]

Some species of sorghum can contain level of hydrogen cyanide, nordinine and nitrates lethal to grazing animals in early stage of the plant growth. The second major component of sorghum is protein. In sorghum variability is large because the crop is grown under diverse agro climatic condition which affects the grain composition. Fluctuations in the protein content of the grain are generally accompanied by changes in the amino acid composition of the protein. The quality of protein is primarily a function of its essential amino acids composition of the protein. The most limiting amino acid is lysine. The primary protein of dietary protein is to satisfy the bodies need for nitrogen and essential amino acids. [18]

The method differs due the variation of ingredients that means as the number of ingredients increase, the duration of preparation also increases. Konso's cheka takes the shortest time for preparation which is about three days since its ingredients are less in number and this is the reason why we prefer this method in our work. It is difficult for konso peoples to stay without cheka. It is their special food which they want to have it every time and everywhere.

The genetic variant that accumulate more, sugar and less starch in the ear is consumed as vegetable and called a sweat corn. Immature maize shoots accumulate a powerful antibiotic substance/DIMBOA (2,4-dihydroxy-7-methoxy-1,4-benzoxazine-one ). Because of its shallow root, maize is susceptible to drought; intolerant of nutrient deficient soils and prone to be up rooted by sever winds. [7]

Carbohydrates occur in every living organism. The sugar and starch in food and the cellulose in wood, paper and cotton are nearly pure carbohydrates. Modified carbohydrates are part of the nuclide aid that carries out genetic information and still others are used as medicine. The word carbohydrate derived historically form the fact that glucose, the first simple carbohydrate to be obtained pure, has the molecular formula $\mathrm{C}_{6} \mathrm{H}_{12} \mathrm{O}_{6}$ and was originally through to be anhydrate of carbon, $\mathrm{C}_{6}\left(\mathrm{H}_{2} \mathrm{O}\right)_{6}$. Today the term carbohydrate is used the name persisted. Today the term carbohydrate refers to the broad class of poly hydroxylated aldhydes and ketones, commonly called sugar. [6]

\subsection{Statement of the Problem}

Konso peoples take the upper hand in using cheka, and they have a long history with it. These peoples are the first in the southern part of Ethiopia to use cheka as a food. Derashe peoples are the second, next to Konso peoples to use cheka, but the ingredients and methods of preparation of cheka in different places has a slight difference. As they are farmers, their work needs high energy and once they consume cheka, they will not fill any tiredness, and not easily affected by disease, being fun and sociable. The method they use to prepare cheka is not that much safe. By considering those energetic and motivational, sociability effects of cheka on the individuals, conducting this research work is necessary.

\subsection{Objectives of the Study}

\subsubsection{General Objectives}

1. Characterization and estimation of biomolecules in the local food and drink cheka.

\subsubsection{Specific Objectives}

a. Identification of proteins and carbohydrate in cheka.

b. Estimation of proteins and carbohydrates in cheka.

c. Estimation of alcohols in cheka.

d. Assessing the health condition of people who use cheka.

\section{Literature Review}

Cheka is a local drink which mostly used in Derashe and Konso special woredas in the southern part of Ethiopia. Konso is the primary origin of cheka from which it is distributed to the neighboring areas around it, due to its suitability to perform high energy requiring activities like farming and others. It is prepared from maize and sorghum. These crops are common in the area because the condition and the type of soil around Konso and Derashe are suitable to grow those crops. Cheka is a mixture of maize, sorghum, water and malt. On the preparation, the ingredients pass through fermentation and other organic reactions and alcohols, aldhydes and carboxylic acids are the major 
contents of chemicals in cheka, Maize, sorghum and malt have different nutrients including carbohydrates, proteins and lipids.

\subsection{Maize}

Maize is also known by the name corn which is grass domesticated by indigenous peoples in meso America in pre historic time. Especially Aztecs and Mayas then spread over the world. Maize stem resembles bamboo tens and the internodes can reach $22-30 \mathrm{~cm}$ and the stem height reaches to 2-3 cm. Maize has ten chromosomes and the combined length of the chromosome is $1500 \mathrm{~cm}$. Its shortage causes comsmut which is fungi disease, maize dwarf mosaic virus and common rust. [8]

Most of the time maize is used as a food for humans and animals for production of alcohols and biscuit foods. Starches from maize can also be used to make plastics, adhesive corn silk are sold as herbal supplements. Alcohols obtained from maize can use as bio fuel like that of wood. It also used as feedstock for the production of Ethanol fuel. [18]

Maize is the leading livestock food in North America. In much of the world particularly Latin America and parts of Africa and Asia, it is the basic serial in human diet. Yet its deficiency as the sole source of protein has been recognized for years. Native Americans seemingly knew this. For they often incorporated beans in their diet. In early century Osborn and Mendel in 1914 found that the most limiting factor is lysine. The major protein of maize endosperm, Edwin T. Merits improved the amino acid quantity of maize by suppressing the amount of zein. [7]

Malting is the process applied to sereal grains, in which the grains are made to germinate by soaking in water and are then quickly halted from germinating further by drying or heating white hot air. Thus malting is a combination of two processes: the sprouting process and the kiln drying process of brewing for batches of beers or other beverages as they provide more specified information. The term malt refers to several products of the process. The grains to which this process has been applied, for example malted barley, the sugar, heavy in maltose derived from such grains, such as the bakers malt used in various sereals or a product based in malted milk. Malting is the process of converting barley or other crops in to malt, for use in brewing or distilling process. This is done by kiln-drying the sprouted crop this is usually done by spreading the sprouted crops on a perforated wooden floor. The temperature thus employed is usually around $55 \%$ c. [6]

Sorghum is a genus of numerous species of grass, some of which are rises for a grain and many of which are used as fodder plant. The plant is planted in a warmer climate worldwide. Numerous sorghum species are used as food, production of alcoholic beverages as well as bio fuel. Most species are drought tolerant and heat tolerant and are, especially important in rid region. Sorghum species are an important food crop in Africa, central America and south Asia and is the fifth most important serial crop grown in the world. Sweet sorghum syrup is known as molasses although it is not true molasses. [18]

According WHO (1985) in sorghum the chemical score of a protein if calculated in relation to the essential amino acid requirement pattern as reference would be more realistic and inductive of the capacity of the protein to meet human requirements. So for this case sorghum may be able to meet the maintenance requirements in adults. Lysine content was reported to vary form 71-212 mg per gm of nitrogen and the corresponding chemical varied from 21 to $62 \mathrm{mg}$, the crude fat content of sorghum is $3 \%$ which is higher than that of wheat and rice, but lower than maize. The germs itself provide about $80 \%$ of the total fat. The fatty acid composition of sorghum fat is $49 \%$ linglic acid $31 \%$ oleic, $14 \%$ palmitic, $2,7 \%$ linolenic and $2.1 \%$ stearic, which was similar to that of corn fat, but was more unsaturated. In the sorghum kemel the mineral matter is unevenly distributed and is more concentrated in germs and seed coat. Sorghum contains metals like zinc, magnesium, iron, copper and others sorghum are rich source of Bcomplex vitamins yellow endosperm varieties of sorghum are likely to be of little importance as dietary source of vitamin A precursor. Detectable amount of other fat soluble vitamins like $\mathrm{D}, \mathrm{E}$ and $\mathrm{k}$ has been found in sorghum grain. Sorghum is not source of vitamin C. Among B group vitamins, concentration of thymine, riboflavin and niacin in sorghum were comparable to those in maize sorghums may have different uses like bread, injera and porridge and traditional beverages. [18]

Pure starches were able to be isolated from red and white sorghum. The amylase content in white sorghum starch which is about $27.1 \%$ was slightly higher than that in red sorghum which is about $24.8 \%$. The swelling power and the solubility behavior of both starches were nearly similar below $65^{\circ} \mathrm{C}$. At higher temperature, starches has isolated form white sorghum cultivar showed higher swelling power and lower solubility index than pigmented sorghum starch. The physicochemical and functional property of sorghum cultivar starch is influenced by the genotype and environment. [11]

Malts often divided in to two categories by brewer: base malts and special malts. Base malts have enough diastatic power to convert their own starch and usually that of some amount of starch from unmalted grain. Crystal malts are special malts that have been subjected to heat treatment that converts their starches to sugars non-enzymatic ally. Malted grain is used to make malt beer, malt Wisk, malted shake; malt vinegar. Malted barley is often label listed ingredient in blended flaurs typically used for yeast breads. Malting grains develops the enzymes that are required to modify the grains starch in to sugars, including monosaccharide and disaccharides. It also develops other enzymes such as protease which breaks down the protein in the grain in to forms which can be utilized by yeasts. Barley is the most commonly malted grain in part because of its high diastatic power of enzyme content. Other grains may be malted specially wheat and maize. [4]. 


\subsection{Carbohydrates}

Carbohydrates are synthesized by green plants during photosynthesis, a complex process in which sunlight provide the energy to convert carbon dioxide and water in to glucose plus oxygen. Many molecules of glucose are then chemically linked for storage by been estimated that more than $5 \%$ of the dry weight of earth biomass, all plants and animals consists of glucose polymers. When eaten and metabolized carbohydrates provide the major source of energy required by organisms. Thus carbohydrates act as chemical intermediates by which solar energy is stored and used to support life. Animal tissues contain glycogen and body fluid contain glucose both of which are carbohydrates. [8]

\subsubsection{Classification of Carbohydrates}

\section{(a). Monosaccharide or simple sugars}

These are compounds with two up to ten carbons per molecule or dioses to decoses). The more important one have between three to six carbons (trioses, tetrose, pentose hexose)

They are colorless, crystalline compounds, readily soluble in water and sweetish to taste. Their solutions are optically active and inhabit the phenomena of muta rotation. Reduction of aldehyde or Kenton group to form sugar alcohols. On treatment with hydrogen in the presence of catalyst, the aldehyde or ketone group is reduced to an alcohol group. Mild oxidizing agents like bromide, water oxidize the $\mathrm{CHO}$ to $-\mathrm{COOH}$ to form sugar acids. Strong oxidizing agents like nitric acid on the other hand, oxidize the aldhyde groups as well as the primary alcoholic group to produce sugar acid called saccharin acid. [20]

i. Esterification

The alcohol group may react with acids to form esters under suitable condition. The phosphoric acid esters of sugar are important as intermediate products formed during metabolism in the body.

Reducing action of monosaccharide in alkaline medium, the aldhyde or ketone group can reduce a number of substances like silver, bismuth, mercuric and cupric salts to metallic silver, bismuth mercury and cuprous hydroxide or oxide. Fericcyanide is reduced to ferro cyanide. Simple laboratory tests for sugars usually employ the reduction of cupric salts to cuprous salt. [12]

ii. Fehling reagent

Fehliling reagent contains cupric sulfate in a solution of $\mathrm{NaOH}$ and sodium potassium tartarate. While sodium hydroxide provides alkaline mediums, the purpose of sodium potassium tartarate is to keep the cupric hydroxide in solution by forming a complex with it. [12]

iii. Benedict reagent

Benedict reagent contains cupric sulphate in solution of sodium carbonate to provide an alkaline medium, and sodium citrate to keep the cupric hydroxide in solution. This is the most commonly used reagent to test urine for reducing substances. A positive test with either of the reagent is indicated by the formation of a yellow precipitate of cuprous oxide or a brick red precipitate. [12]

Oxidation of Monosaccharides
Like other aldhydes, aldoses are easily oxidized to yield the corresponding mono carboxylic acid called aldonic acid.

Aldose react with tollens reagent $\left(\mathrm{Ag}^{+}\right.$to in $\left.\mathrm{NH}_{3}\right)$ Fehling reagent $\left(\mathrm{cu}^{2+}\right.$ in aq sodium potassium tartarte) or benedict reagent $\left(\mathrm{cu}^{2+}\right.$ in aq. Sodium citrate) to yield the oxidized sugar and reduced metallic species. All three reactions serve as a simple chemical test for reducing sugars. Reducing because the sugar reduces the oxidizing agent. If tollnes Reagent is used metallic silver is produced as a shiny mirror on the walls of the reaction flask (test tubes). if fehling or benedict reagent is used a reddish precipitate of copper (II) oxide signal appositive result some diabetes self, test kits sold for home use still employ the benedict test, although more modern method have largely replaced the chemical test as little as $0.1 \%$ glucose in urine gives appositive result all aldoses are reducing sugar because they contains an aldhyde carbonyl group but some ketos are reducing sugar as well fructose is reduce toll en's reagent for example even though it contains no aldhyde group. Reduction occurs fructose is readily isomerized to an aldose in basic solution by serious of keto-enol tautomeric shifts. [1]

\section{(b). Disaccharides}

These are formed by union of two monosaccharide. They are united by linkage between the first carbon of one monosaccharide with the second or the fourth carbon of another monosaccharide by what is known as glycosidic linkage, the structure of the three biologically important sugars, maltose, lactose and sucrose they important sugars, maltose, lactose and sucrose they are colorless crystalline substance, readily soluble in water and sweetish to taste.

i. Maltose

This is made up of two Alfa D - glucose white united by the 1.4-glcosidic linkage maltose is formed during the digestion of starches by enzymes or dilutes acid.

\section{ii. Lactose}

This is made up of molecules of Alfa D-glucose united by 14-glycosidic linkage of molecule of Beta D-glactose. The aldhyde group of glucose remains free and exhibits the properties due to the group

iii. Sucrose-

It is made up of one molecule of Alfa-D-glucose and one molecule beta D-fructose united by aglycosidic linkage between the aldhyde and keto groups.

\section{Reducing Disaccharides}

Cellobiose - results from the hydrolysis of cellulose by bacteria. It contains constitution materials such as cotton and paper. Maltose is a home polymer of cellobiose

Iso Maltose, Is formed from two glucose monosaccharide. It often found at the branching point of amylo pectin and glycogen.

Lactose, Lactose is the predominant disaccharide found in milk. Its intolerant is condition in which there is lack of the enzyme lactase. Galactosamiam is a condition that results from un inability to process the D-galactose after hydrolysis

Maltose, Maltose results from hydrolysis of starch by enzymes in the mammalian digestive track. It is used as sweetener and as a substrate for fermentation. It is also the 
constituent of the enzyme polymer amylase. Manobiase, Manobiase is the unit for the plant polysaccharide mannane. Sucrose, Sucrose is the predominant disaccharide found in sugar cane and sugar beet. It is a well-known sweetener and has five membered faranosyl units. Trehalose, Trehalose is found in microbes, fungi and certain insects.

\section{(c). Polysaccharides}

Several monosaccharide molecules combine to form polysaccharides. They have high molecular weight and are only sparingly soluble in water in the cold. They are not sweetish and do not exhibit any of the properties of aldhyde or keto groups where the polysaccharide is made up of several units of one monosaccharide, only is made up of several units of one monosaccharide only it is called homopolysaccharide, example starch glycogen, cellulose, dextrin and agar. Where it contains more than one monosaccharideit called hetropolysaccharide, example pectin and mucopolysaccharides. [9]

Glycogen is also known as animal starch since it is the main poly saccharine occurring in animal tissues particularly in liver and muscle. Oysters and certain verities of rice are also glycogen like starch these is also polysaccharide made up of glcose units by 1,4- linkage and branches arising by 1,6- linkages but the branches occur at shorter intervals and give more compact tree-like structure. The molecular weight is about 4,000.000 Glycogen gives reddish brown tint with iodine. [15]

Cellulose is the chief constituent of the woody fiber portion of plant material and is the most abundant of all carbohydrates in water. It is made up of long chain of beta Dglucose molecules united by 1,4- linkages. There is no branching. The enzyme cellulite can hydrolyses cellulose, but the enzyme is present only in bacteria, hence cellulose is not utilizable by man, but, it serves the function of increasing the bulk of the food thus giving a sense of satiety. [10]

Sweetness, Say the word sugar and most people immediately think of sweet tasting candies, disserts and such. In fact most simple carbohydrates do taste sweet, but the degree of sweetness vary with sucrose or table sugar as reference point, fructose is nearly twice as sweet but lactose is only about one-six sweet. Comparisons are difficult, though because perceived sweetness depending on the concentration of solution being tasted. [9]

\section{Protein}

The name protein is taken from the Greece protios means first. This name is well chosen of all chemical compounds, proteins must almost certainly be ranked first, for they are the substance of life. Proteins are macro molecules. They are constructed form one or more an unbalanced chains of amino acids, that is they are polymers. Atypical protein contains 200-300 amino acids, but some are much smaller (the smallest are often called peptides) and some much larger (the larges is titin which is a kind of protein that is found in skeletal and cardiac muscles, on version contains 34, 350 amino acids in a single chain proteins are probably the most important class of biochemical. [15]

\section{Amino Acids}

When we eat foods that contain protein, the digestive juices in our stomach and intestine go to work. They break down the protein in food in to basic units called amino acids. The amino acids then can be reused to make the proteins our body needs to maintain in muscles, bones, and blood and body organs. Scientists have found many different amino acids in protein. Out of 22 amino acids our body can make thirteen of them without our thinking about it. Our body cannot make the other nine amino acids, but we can get them by eating protein rich foods. They are called essential amino acids because it is essential that we get them from the food we eat. [3]

\subsubsection{Classification of Amino Acids}

Amino acids can be classified in to three groups depending on their reaction in solution, neutral, acidic and basic

a. Neutral Amino Acids

This comprises the largest group and can be further sub divided in to aliphatic, aromatic heterocyclic and sulfur containing amino acids. They all have one amino group and one carboxylic group

Aliphatic amino acids, Aliphatic amino acid includes glycine (the smallest amino acid) alanine, serine, threonine, valine, leucine and isoleucine.

Aromatic amino acide, This includes phenyl alanine, Tyrosine, and tryptophan sulfur containing amino acids. Amino acids categorized under this are, cystine, methionine

Acidic Amino Acids, The amino acids like aspartic acid, asparagines, glutamic acid, and glutamine are classified under this category.

Basic Amino acids, Only Arginine and lysine are under basic amino acids.

\section{Occurrence of Amino Acids}

All the 20 amino acids listed above occur in almost all proteins. Lysine being as mall molecule, usally occupies positions where the peptide chain takes a bend. The hydroxide of serine and-SH of cystine are nucleophiles and take active part in enzymatic actions. They also serve as sites for phosphorylation, dephosphorylation reactions in enzymes and help regulation of enzyme activities. Histidine plays unique role in enzyme actions. The imidazole proton can act as acid or basic catalyst at PH 7.0. The acidic amino acids aspartic and glutamic are particularly rich in sereal protein of connective tissues e.g collage $\mathrm{n}$. A few other amino acids or their derivatives occur in tissues as intermediate products during metabolic processes and will be considered at the appropriate time. Although the amino acids are commonly shown as containing an amino group and carboxylic group, certain properties, both physical and chemical properties are not constituent with this structure. In contrast to amino and carboxylic acids, the amino acids are non-volatile at high temperature. They are insoluble in non-polar solvents like petroleum ether, benzene, and ether and appreciably soluble in water. Their aqueous solution behave like solutions of substance of high dipole moment. [11]

Reactions of Amino Acids

When amino acids are heated with ninhydrine, the amino 
group is removed and a condensation product is formed with ninhydrin which has a bright blue color. This can be sued for colorimetric estimation of amino acids and in staining chromatographic staining, chromatographic strips proline and hydroxyl proline give a yellow color to ninhydrin reaction.

\subsection{Alcohols}

\subsubsection{Simple Alcohols}

The most commonly used alcohol is ethanol $\left(\mathrm{C}_{2} \mathrm{H}_{5} \mathrm{OH}\right)$ with the ethane backbone. The simplest alcohol is methanol which was formerly obtained by the distillation of wood. It is mainly used as a solvent, fuel and raw material.

PROPERTIES:-Alcohol has an odour that is often described as biting and as hanging in the nasal passage. The hydroxyl group makes the alcohol molecule polar. This alcohol can be used as protic solvent due to the presence of hydroxide to promote solubility in water and of the carbon chain to resist it. Alcohols $f$ five or more carbons are effectively insoluble in water, because of the hydrocarbon chains dominance, but all simple alcohols in organic solvent. Alcohols have higher boiling point compared to hydro carbons. Alcohols like water show either acidic or basic properties at the hydroxyl group. With a PKa of around 16-19 they are generally slightly weaker acids than water Unlike ethanol, methanol is extremely toxic and it may cause permanent blindness in low doses $(15 \mathrm{ml}$ and death in larger amount (100-250).

\section{Ethanol}

Ethanol was one of the first organic chemical to be prepared and purified. Its production by fermentation of grains and sugar has been carried out for millennia, and its purification by distillation goes back at last as far as the twelfth century. Ethanol for non beverage use is obtained by acid catalyzed hydration of ethylene. The production of ethanol by fermentation of grains and sugars is one of the oldest known organic reactions, going back at last 2500 years. Fermentation is carried out by adding yeast to an aqueous sugar solution, where enzymes break down carbohydrates in to ethanol and carbon dioxide.

$$
\mathrm{C}_{6} \mathrm{H}_{12} \mathrm{O}_{6}+\text { Yeast } \rightarrow 2 \mathrm{CH}_{3} \mathrm{CH}_{2} \mathrm{OH}+2 \mathrm{CO}_{2}
$$

Ethanol is classified for medical purpose as a central nervous system depressant. Its effect (that is being drunk) resembles the human response to anesthetics.

There is an Initial excitability and increase sociable behavior, but this results from depression of inhibition rather stimulating.

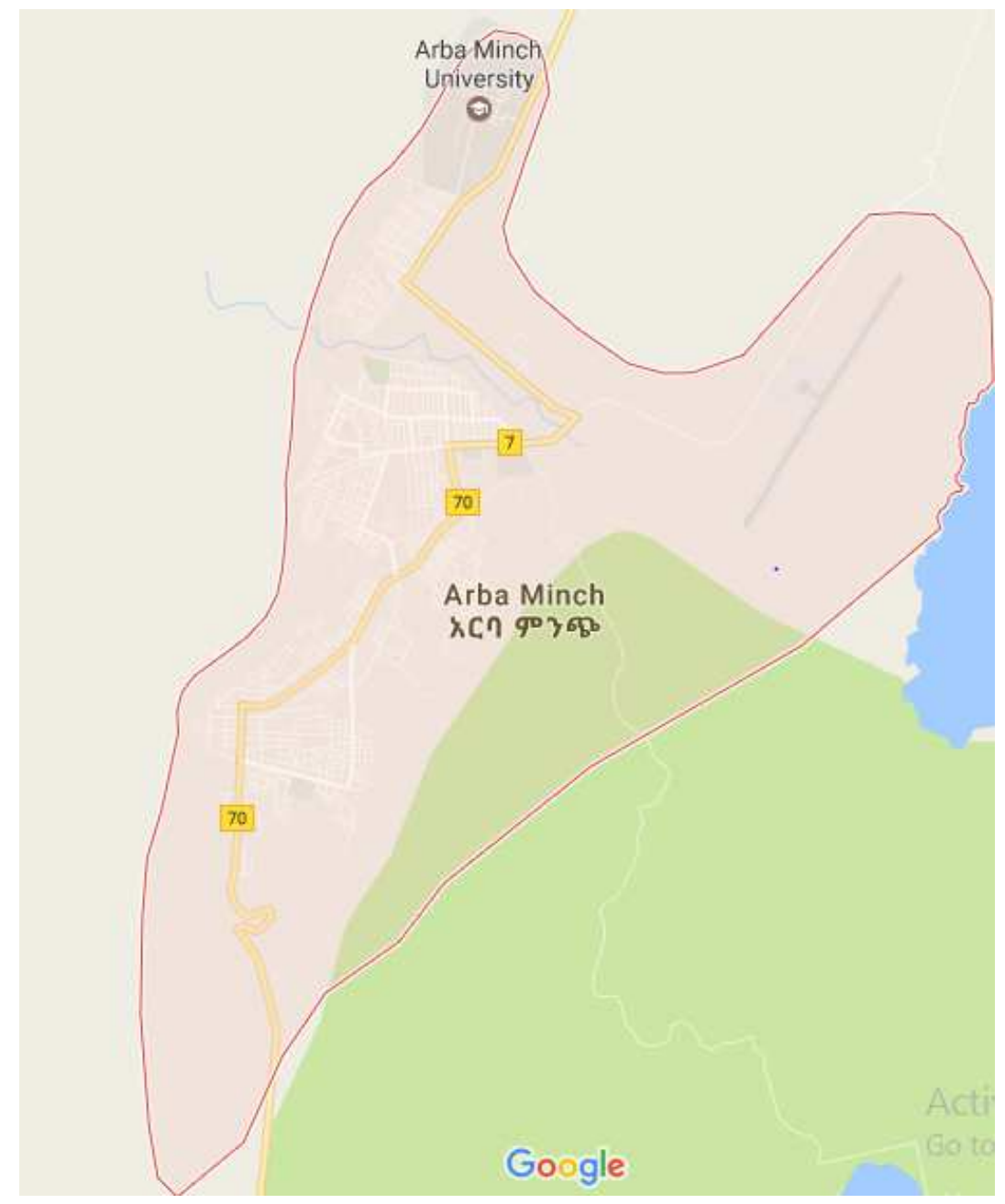

Figure 1. Map of Arbaminch town. 
At blood alcohol concentration of $0.1-0.3 \%$ or $100-300$ $\mathrm{mg} / 22$ motor coordination is affected, accomplished by loss of balance slurred speech and amnesia when blood alcohol concentration rises to $0.3 \%-0.4 \%$ nausea and loss of consciousness occur above $0.6 \%$ spontaneous respiration and cardiovascular regulation are affected, ultimately leading to death in the pituitary gland ethanol inhibits the production of hormone that regulates urine flow causing increased urine production and dehydration. In the stomach ethanol stimulates production of acid. The metabolism of ethanol occurs mainly in the liver and proceeds by oxidation in two steps. The first to acetaldehyde and then to acetic acid. Ethanol and acetaldehyde are toxic leading a devastating physical and metabolic deterioration in chronic alcoholics. Liver is usually suffers to worst damage since it is the major site of alcohol metabolism. [6]

\subsubsection{Oxidation of Alcohols}

One of the most valuable reaction of alcohol is their oxidation to yield carbonyl compounds. The opposite of reduction to yield an alcohol. Primary alcohols yield aldehyde or carboxylic acids, secondary alcohols yield ketone, and tertiary alcohols do not normally react with most oxidizing agents. The oxidation of primary or secondary alcohols can be accomplished by any of a large number of reagents including $\mathrm{KMnO} 4, \mathrm{Na} 2 \mathrm{Cr} 2 \mathrm{O} 7$. Which reagent is use in specific cases depends on such factor as cost, convenience, reaction yield, and alcohol sensitivity. for example, the large scale of oxidation of a simple inexpensive alcohol such as cyclohexanol would best be done with a cheap oxidant such as sodium dichromate. On the other hand the small scale oxidation of a delicate and expensive poly functional alcohol would best be done with a mild and high yielding reagent, regardless of cost primary alcohols are oxidized either to aldehydes or carboxylic acids, depending on the reagent chosen and the condition used, probably the best method of preparing aldehyde form primary alcohol on laboratory scale is by use of pyridinium chloro chromate. Most other oxidizing agents like $\mathrm{CrO} 3$ in aqueous acid, oxidize primary alcohol to carboxylic acid. an aldhyde is involved in this reaction but cannot usually be isolated because it is further oxidized too rapidly. Secondary alcohols are oxidized easily and in high yield to give ketone. [2]

\section{Methodology}

\subsection{Study Area: This Research Was Conducted at South Ethiopia, Arbaminch Town}

Sample size: randomly about twenty one individuals who use cheka regularly as a sample and determined their /BMI/ Body mass index.

\subsection{Sample Preparation}

To do this research, I begin with collecting the necessary ingredients like maize, sorghum and malt from Arba Minch town. The method of preparation was obtained from Konso safer peoples who use cheka as means of income. After getting the method of preparation, I prepared my own cheka in the laboratory following the procedures. Using the prepared cheka, carried out different Tests like alcohol test, carbohydrate test and protein tests, I also estimated the amount of protein using spectrophotometer and the amount of carbohydrates that present in cheka using Benedict test.

i Cheka preparation in different places has a slight difference in the method of preparation and the ingredients used to prepare cheka in different areas are also different, although the name given to all is cheka.

ii Among the different methods and ingredients, we did according to the procedures that konso peoples use in Arbaminch town konso safer.

iii Konso people use maize, sorghum and maize malts an ingredient to prepare cheka, but in others like gidole , cabbage and moringa leafs are used as ingredient in addition to the ingredients that are used by konso people.

iv The procedure or the method that konso people use to prepare their cheka after all the necessary ingredients are obtained is as follows.

$\mathrm{v}$ Equal quantity of white and red sorghum powder were mixed with white maize powder

vi Then water was added to the mixed powders.

vii The mixture was allowed for two days to undergo fermentation, and additional powder was added to facilitate for cooking after one day.

viii The facilitated mixture was then cooked after one day (the mixture was shaped in rolled form before cooking)

ix After it was cooked and kurkufa was formed, the rolled form is converted to powder form by grinding.

$\mathrm{x}$ The grinded kurkufta was allowed for a few hours in open air for cooling.

xi Then the cooled kurkuffa was mixed with maize malt which was one-fourth of the amount of kurtufta and the malt was distributed to all part of powder.

xii The mixture was stored in dish with addition of small amount of water and covered with aluminum foil

xiii After one day the crude cheka would be diluted with water according to the interest of the drinker and cheka as a final product was obtained.

Test for carbohydrates

a. Iodine test

A few drops of iodine solution were added to about $1 \mathrm{ml}$ of the test solution.

b. Fehling test

$1 \mathrm{ml}$ of fehling solution " $\mathrm{B}$ " was added to $1 \mathrm{ml}$ of test solution "A" and a few drops of cheka was added. The mixture was boiled for a few minutes.

c. Benedict's test

Five drops of the cheka solution was added to $2 \mathrm{ml}$ of benedict's reagent. It was boiled for five minutes in a water bath. The solution was cooled.

Protein tests 


\section{a. Biuret Reaction}

$2 \mathrm{ml}$ of $10 \% \mathrm{NaOH}$ was added to $2 \mathrm{ml}$ of cheka solution. Two drops of $0.1 \% \mathrm{CuSO} 4$ solution was added.

b. Ninhydrin Test

$1 \mathrm{ml}$ of $0.1 \%$ freshly prepared Ninhydrin solution was added to $4 \mathrm{ml}$ of the solution. The contents was mixed and boiled for a couple of minutes. It was cooled

Tests for Alcohols

a. Test with Tollen's reagent

A small amount of cheka solution was taken in the test tube and 5 drops of Tollen's reagent was added, and then few drops of sodium hydroxide wete added. The test tube was heated in water bath for more than 15 minutes

b. Jones Reagent test $\left(\mathrm{CrO}_{3}-\mathrm{H}_{2} \mathrm{SO}_{4}\right.$ in $\left.\mathrm{H}_{2} \mathrm{O}\right)$

$1 \mathrm{ml}$ of acetone was placed in a test tube and $1 \mathrm{ml}$ of cheka solution was added in it. One drop of the reagent was added to the acetone solution and the tube was shacked to mix the contents.

c. Test with sodium metal

Small amounts of sodium metal were taken in a dry test tube and a few drops of alcohol were added.

Procedure for spectrophtometric Determination of protein in cheka Biuret solution I

1. 12.5 grams of sodium potassium tartrate in $100 \mathrm{ml}$ of $0.2 \mathrm{~N} \mathrm{NaOH}$. 3.75 gms of copper sulfatepentahydrate $\left(\mathrm{CuSO}_{4} .5 \mathrm{H}_{2} \mathrm{O}\right)$ was added to the prepared solution with stirring.

2. $1.25 \mathrm{gm}$ of $\mathrm{kI}$ was added after copper sulfate was dissolved and the volume was made up to $250 \mathrm{ml}$ white $0.2 \mathrm{~N} \mathrm{NaOH}$.

3. $0.99 \%(\mathrm{~W} / \mathrm{V}) \mathrm{NaCl}$ solution was prepared and also $1.0 \% \quad(\mathrm{w} / \mathrm{v})$ egg albumin (protein standard) was prepared and it was added to $0.9 \% \mathrm{NaCl}$.

4. Six test tubes were prepared. The first test tube for blank solution with $1.2 \mathrm{ml}$ of $0.9 \% \mathrm{Nacl}$.

5. $1.0 \mathrm{ml}$ of $0.9 \% \mathrm{NaCl}$ solution and $0.2 \mathrm{ml}$ of protein standard were added to the second test tube.

6. $0.8 \mathrm{ml}$ of $0.9 \% \mathrm{NaCl}$ solution and $0.4 \mathrm{ml}$ protein standard were added to the third test tube.

7. $0.6 \mathrm{ml}$ of $0.9 \% \mathrm{NaCl}$ and $0.6 \mathrm{ml}$ of protein standard were added to the fourth test tube.

8. $0.4 \mathrm{ml}$ of $0.9 \% \mathrm{NaCl}$ Solution and $0.8 \mathrm{ml}$ of protein standard were added to the fifth test tube.

9. $0.2 \mathrm{ml}$ of $0.9 \% \mathrm{NaCl}$ Solution and $1.0 \mathrm{ml}$ of protein standard were added to the last test tube.

$10.0 .2 \mathrm{ml}$ of $0.9 \% \mathrm{NaCl}$ Solution and $0.2 \mathrm{ml}$ of cheka solution were added to the first sample test tube.

$11.1 \mathrm{ml}$ of $0.99 \% \mathrm{NaCl}$ solution and $0.5 \mathrm{ml}$ of cheka solution were added to the second sample test tube.

12.4.0ml of Biuret reagent was added to each test tube.

A. The tubes were mixed carefully. After 15minutes of incubation at room temperature, the Absorbance of each tube was measured at a wave length of $546 \mathrm{~nm}$. The measured absorbance was plotted versus the protein concentration and the concentration of protein in cheka was estimated.

\section{Results and Discussion}

Table 1. Laboratory tests and their observation on alcohol, protein and carbohydrate.

\begin{tabular}{llll}
\hline$\#$ & Test solution & Chemical to be tested & observation \\
\hline 1 & Tollen's reagent & Alcohol & Formation of silver mirror \\
2 & Jones's reagent & Alcohol & Disappearance of orange color immediately \\
3 & Sodium metal & Alcohol & Evolution of hydrogen gas \\
4 & Biuret solution & Protein & Formation of pink color \\
5 & Ninhydrin solution & Protein & Appearance of pink color \\
6 & Benedict solution & Carbohydrate & Green precipitate $(0.5-1) \mathrm{mg} / \mathrm{L}$ \\
7 & Fehling solution & Carbohydrate & Formation of yellow precipitate \\
8 & Iodine solution & carbohydrate & Appearance of deep blue color \\
\hline
\end{tabular}

Table 2. Concentration of the standards and unknown sample used for absorbance measurement.

\begin{tabular}{lll}
\hline NO & Concentration of standard (mg\%) and unknown volume of sample & Absorbance(546nm) \\
\hline Test tube 1 & 0 & 0.00 \\
Test tube 2 & 1 & 0.05 \\
Test tube 3 & 2 & 0.101 \\
Test tube 4 & 4 & 0.187 \\
Test tube 5 & 6 & 0.290 \\
Test tube 6 & 8 & 0.389 \\
Test tube 7 & 10 & 0.460 \\
Test tube 8 & Sample 1 & 0.120 \\
Test tube 9 & Sample 2 & 0.131 \\
\hline
\end{tabular}

Table 3. The following table contains weight and height of peoples who uses cheka frequently.

\begin{tabular}{llllll}
\hline No & Sex & age & Height & Weight & BMI \\
\hline 1 & M & 24 & 1.67 & 66 & 23.665 \\
2 & M & 20 & 1.66 & 64 & 64 \\
3 & M & 25 & 1.68 & 23.225 & 78 \\
4 & M & 24 & 1.73 & 22.676 & 78.062 \\
\hline
\end{tabular}




\begin{tabular}{llllll}
\hline No & Sex & age & Height & Weight & BMI \\
\hline 5 & M & 25 & 1.73 & 79 & 25.796 \\
6 & M & 20 & 1.71 & 75 & 25.796 \\
7 & M & 22 & 1.66 & 62 & 25.059 \\
8 & M & 22 & 1.72 & 66 & 22.4996 \\
9 & M & 23 & 1.65 & 63 & 23.140 \\
10 & M & 23 & 1.65 & 22.038 \\
11 & M & 20 & 1.62 & 58 & 22.1 \\
12 & M & 19 & 1.85 & 78 & 2.79 \\
13 & F & 33 & 1.60 & 67 & 26.177 \\
14 & F & 23 & 1.55 & 60 & 29.054 \\
15 & M & 36 & 1.68 & 82 & 30.478 \\
16 & M & 28 & 1.67 & 85 & 24.691 \\
17 & M & 32 & 1.80 & 70 & 24.802 \\
18 & M & 26 & 1.68 & 62 & 26.639 \\
19 & F & 20 & 1.55 & 67 & 24.314 \\
20 & F & 23 & 1.66 & 70 & 25.712 \\
21 & F & 25 & 1.65 & & \\
\hline
\end{tabular}

** Weight and height of cheka users with BMI ranges

1. Table one (1) contains test solution like Tollen's reagent, jones's reagent and sodium metal for determination of alcohol in cheka. Biuret and Ninhydrin solution for the determination of protins, and Benedict, fehling and iodine solution for determination of carbohydrate.

2. On testing of carbohydrate, proteins and alcohols using the above test solution, positive results are obtained for all tests. This shows us how much cheka is rich in carbohydrate, protein and alcohol . A basic amino acid lysine that is found in maize and sorghum is the main source for carbohydrate and the fermentation of sugar is the source for alcohol (ethanol) present in cheka as we presented in our literature review.

3. Table two (2) shows as the concentration of sample and proteins standards with their absorbance obtained from spectrophotometric determination at a wave length of $546 \mathrm{~nm}$. As we can see from table three (3), thirteen of the individual which mean more than half of the total individual have a body mass index (BMI) in the range of 18.5-24.9, and seven of them have a body mass index (BMI) in the range of 24.9-29.9. only one in dividual has a body mass index (BMI) of 30.478 which is in the range of 29.9-9-34.9.

4. From the result of body mass index (BMI) of the individuals, we can easily understand as more than half of the individuals among the total 21 , individuals have a normal health condition, so this shows the positive impact of cheka on these thirteen individuas. Seven individuals are overweight, but this doesn't mean that they are not health, even if they are out of normal range. Only one person among all the 21 individual is obese which indicates as this individual is somewhat in danger since some serious diseases like hypertension, heart attack and others may be caused due to obesity but we can't say this person become obese due to his consumption of cheaka, since 20 of the individual are almost normal.

\section{Recommendation}

As we have seen, cheka has different uses like energizing effect on the users, building up of their body, making of them being initiative and makes them good worker, even if it has the advantage that listed above, it will lose its use if it is not prepared well. For instance as the right time of drinking of the cheka is passed which means oxidation of ethanol to acid is taken place. It will affect our stomach and leads to gastriaseos, so we recommend those peoples who use cheka as means of income, to prepare their cheka in a safe manner and also for user to drink at the right time.

\section{Conclusion}

Different test for characterization of biomolecules confirms the presence of carbohydrates, proteins and alcohols and some quantitative tests give us the concentration of carbohydrates and protein present in cheka. Formation of green precipitate when is treated with benedict solution indicates the presence of carbohydrate in cheka and also tells us the concentration of carbohydrate in cheka is in the range of $5-1 \mathrm{mg} / 1$. Formation of yellow precipitate upon addition of fehling solution to the cheka sample confirms the presence of carbohydrate.

The development of blue color on addition of iodine solution to the cheka sampleis due to the presence of carbohydrates. The pink color formation during the addition of biuret solution and the appearance of violet color up on addition of Ninhdrin solution to the cheka sample is due to presence of protein, Silver mirror formation during addition of tollen's reagent to cheka sample is a signal for the presence of alcohol in cheka. The disappearance of orange color of jones's reagent immediately after its addition to cheka sample is an indicator for the presence of primary and secondary alcohols.

The concentration of protein obtained from spectrophotometric determination that is $2.74 \mathrm{mg} / \mathrm{l}$. In small volume of cheka -the concentration of protein increases with 
increasing volume of cheka and becomes enough for maintaining health and building up the users of cheka have normal health condition as we seen from the body mass index table. The high content of carbohydrate in cheka is responsible for being energetic for konso peoples and other users of cheka which enables them to carry out hard works and makes them to be motivated to do hard works,

Since carbohydrate is the immediate source of energy the initial excitability and increasing of sociability is due to alcoholic behavior of cheka. The normal taste of cheka is converted to sour taste as time goes due to oxidation of alcohols to aldehydes and further to acid.

\section{Appendix}

Body Mass Index /Bmi/ Range Table

MBI range Status

$<18.5 \quad$ Under weight

18.5-24.9 Normal weight

29.9-34.9 Obese

34.9-39.9 Severely obese or morbidly obese

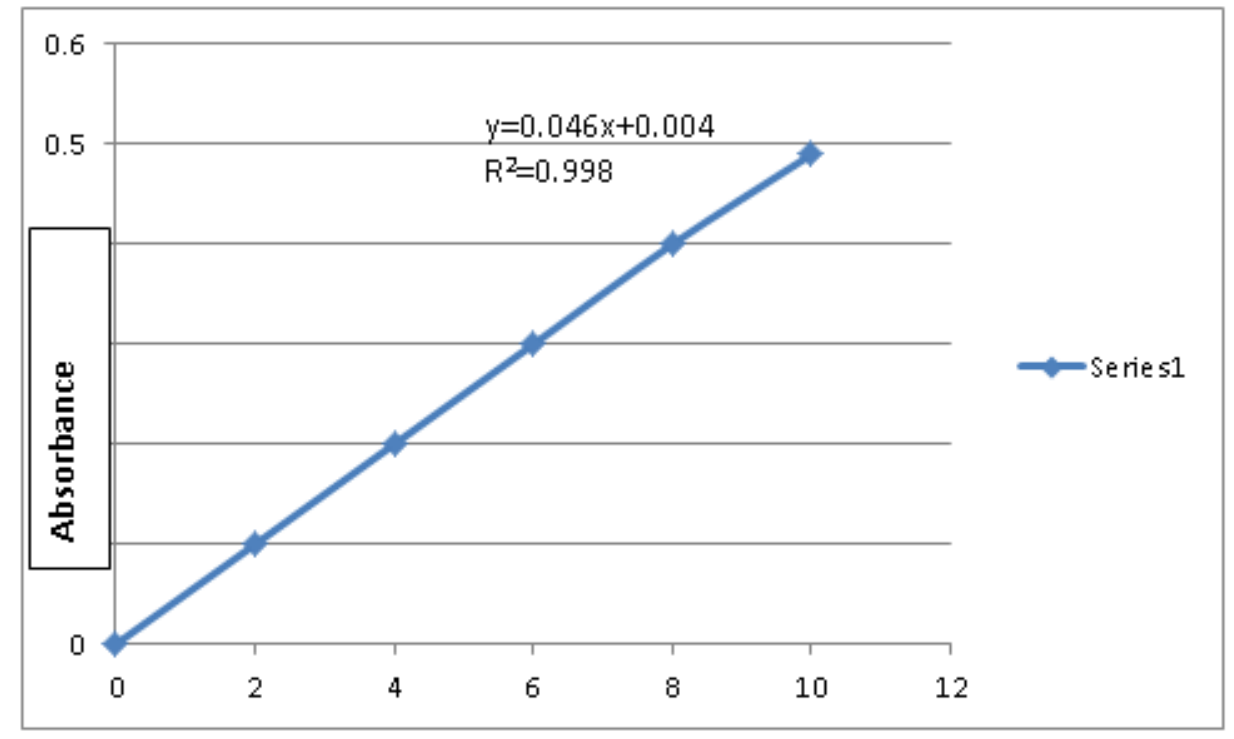

\section{Concentration}

Key: $\mathrm{X}$-axis $=$ concentration and $\mathrm{Y}$-axis $=$ absorbance

Figure 2. Graph for the sample and standards.

Body mass index $(\mathrm{BMI})=\frac{\text { weight of the person }(\mathrm{kg})}{(\text { Height of the person }(\mathrm{m}) 2}$

\section{Acknowledgments}

First of all I would like to express my deep gratitude to my advisor Solomon Tebeje (M. Sc.) for his friendly approach and cooperation in giving necessary information and techniques on the appropriate time and place, and also for his initiation to guide and direct me to generate new ideas that support in doing the research properly. Secondly I would like to thank department of applied chemistry for giving necessary chemicals and materials.

\section{References}

[1] Sadasinam. Sand manickam. A (1991), biochemical method, $3^{\text {rd }}$ edition. page 2-4 and 31-32.

[2] F. Robert and Boyd (1998). General Microbiology. $4^{\text {th }}$ edition, page 55-56.

[3] E. lewis stertevant (1994). Bulleting of the Torrey botanical club, vc 12. Page 1.

[4] C. clarp, 1998, the British malting industry, $2^{\text {nd }}$ edition, page 13.

[5] Watson, Andrew. M. (1983), the diffusion of crops and for Ming techniques, vol. 4, page 24-25.

[6] D. E Briggs, (1998), Malt and malting kluwer academic, $1^{\text {st }}$ edition, page 3-6.

[7] J. k (2000), maize, the oxford English dictionary, $5^{\text {th }}$ edition, page $30-31$.

[8] Duvick, D. N and cassman, K. G (1999), post-green revolution trends in yield potential of temperate maize in the north - central united states vol 39 (6): page (6).

[9] Perahia, D. R. M. levely, and M. karplus. (1990). Motions of anx-helical polyp peptide-comparison of molecular and harmonic dynamics, $3^{\text {rd }}$ edition, page 645-677.

[10] Gardner, K. H and J. Black well, (1974), structure of native cellulose, $2^{\text {nd }}$ edition, page $1975-2001$.

[11] Kadal, J, F, and R. D. Gilbert. (2000), cellulose structure review, $5^{\text {th }}$ edition, paged $197-216$. 
[12] Karplus, M and J, kushick. (1981). Method for estimating the configurationally entropy of macromolecules, $1^{\text {st }}$ edition, page 14-18.

[13] Hockney, R. W. (1970). The potential calculation and some application, $6^{\text {th }}$ edition, page $4-8$.

[14] Abdelrahaman, A, Hoseney, R. C and Varriano - meson, E (1983). Milling process to produce low-aigrettes from pear millet, $3^{\text {rd }}$ edition, page $1-2$.

[15] Adrian, J, muriaside Queroz, M, J and Frangne, R (1970). Lavitamine ppdans lesgrains decereales etde leguminous, $2^{\text {nd }}$ edition, page 32-35.
[16] Alpert, M. E Hutt, S. R, wogan, G wand Davision (1971). Association between aflatoxin content of wood and hepatoma frequency in ugand cancer 25:253-260.

[17] Asquity J. N \& Butler L. C. (1986). Interaction of condensed tannins with selected protein, $1^{\text {st }}$ edition, page $32-33$.

[18] Au. PM and Fields, M. I. (1981). Aresearch note on nutritive quality of fermented sorghum. J. food, $9^{\text {th }}$ edition, page 20-25

[19] Robert Nilson Body, (2006). Organic chemistry, $6^{\text {th }}$ edition, page 14-15.

[20] Ophard Charles E. (2006), virtual chemistry of Elmhurst college, vol 3, page. 